\title{
Article \\ The Use of Sorghum in a Phytoattenuation Strategy: A Field Experiment on a TE-Contaminated Site
}

\author{
Alexandre Perlein ${ }^{1,2, *}$, Valérie Bert ${ }^{1}$, Océane Desannaux ${ }^{1}$, Marcella Fernandes de Souza ${ }^{2}\left(\mathbb{D}\right.$, Arnaud Papin ${ }^{3}$, \\ Rodolphe Gaucher ${ }^{1}$, Isabelle Zdanevitch ${ }^{1}$ and Erik Meers ${ }^{2}$ \\ 1 Clean Technologies and Circular Economy, INERIS, Parc Technologique Alata, BP2, \\ 60550 Verneuil-en-Halatte, France; valerie.bert@ineris.fr (V.B.); oceanedesa@outlook.fr (O.D.); \\ rodolphe.gaucher@ineris.fr (R.G.); isabelle.zdanevitch@ineris.fr (I.Z.) \\ 2 Department of Green Chemistry and Technology, Ghent University, 9000 Ghent, Belgium; \\ Marcella.FernandesDeSouza@UGent.be (M.F.d.S.); Erik.Meers@UGent.be (E.M.) \\ 3 Analytical Methods and Developments for the Environment, INERIS, Parc Technologique Alata BP 2, \\ 60550 Verneuil-en-Halatte, France; arnaud.papin@ineris.fr \\ * Correspondence: alexandre.perlein@ugent.be; Tel.: +33-630-141-817
}

\section{check for} updates

Citation: Perlein, A.; Bert, V.; Desannaux, O.; Fernandes de Souza, M.; Papin, A.; Gaucher, R.; Zdanevitch, I.; Meers, E. The Use of Sorghum in a Phytoattenuation Strategy: A Field Experiment on a TE-Contaminated Site. Appl. Sci. 2021, 11, 3471. https://doi.org/10.3390/ app11083471

Academic Editor: Werther Guidi Nissim

Received: 2 March 2021

Accepted: 7 April 2021

Published: 13 April 2021

Publisher's Note: MDPI stays neutral with regard to jurisdictional claims in published maps and institutional affiliations.

Copyright: (c) 2021 by the authors. Licensee MDPI, Basel, Switzerland. This article is an open access article distributed under the terms and conditions of the Creative Commons Attribution (CC BY) license (https:// creativecommons.org/licenses/by/ $4.0 /)$.

\begin{abstract}
Phytoattenuation combines phytoextraction or phytostabilization with the economic valorization of the biomass produced on the contaminated soil. Sorghum bicolor is a suitable crop for this strategy, as it is known to be metal-tolerant and can be used for biogas or bioethanol production or in strategies toward biofortification. In the current investigation, two cultivars, Biomass 133 and Trudan Headless (HL), were studied in a metal-contaminated $(\mathrm{Cd}, \mathrm{Pb}, \mathrm{Zn})$ field site located in northern France to assess their potential use in a phytoattenuation strategy. The biomass yield and the metal transfer in the produced biomass were monitored in three plots with different pollution levels. Both cultivars were tolerant to high levels of metal pollution in field conditions, with yields similar to that obtained on uncontaminated sites. Neither of the cultivars changed the metal mobility of the soil and both exhibited a metal-excluder behavior. Nevertheless, Cd concentration in the aboveground part of Trudan HL, and of Biomass 133 to a lesser extent, could restrict their use in some valorization options. However, biogas production was possible with the produced biomass, indicating anaerobic digestion to be a possible valorization route for sorghum grown on contaminated sites.
\end{abstract}

Keywords: Cd; sorghum biomass 133; sorghum trudan headless; anaerobic digestion; phytomanagement

\section{Introduction}

Contaminated dust fallout from industrial activities has caused diffuse and long-term contamination of the soil surface on large areas [1]. In some cases, arable lands were affected, such as the agricultural land near the old smelter of Metaleurop [2,3] in northern France [4]. In addition to soil, sediment landfill sites, as a result of canal-dredged sediments, have also been impacted by trace elements (TE), directly by the dust fall or indirectly by soil surface erosion or soil runoff. These contaminations can create risks by their diffusion in environmental compartments or by the local exposure of humans, therefore causing health problems [1]. To resolve this, civil engineering remediation techniques have been developed, such as the excavation of the contaminated soil or soil washing. Nevertheless, these techniques are not adapted to large areas and suffer from high cost and high energy expenditure, besides destroying the local ecosystem and creating new waste streams to manage $[5,6]$.

As an alternative, techniques adapted to large areas and that yield environmental benefits are being developed, such as phytotechnologies [7-9]. Phytotechnologies are less impactful to the local ecosystem by maintaining or enhancing soil functionalities. They are also, a priori, cheaper; however, they are long-term solutions. Phytotechnologies include two different strategies: either the (partial) cleanup of the TE pollution in the soil 
(phytoextraction) or the limitation of the transfer of the TE pollution in the environment (phytostabilization) [10,11]. Phytoextraction can use either hyperaccumulators species, with high TE concentrations in their biomass and low biomass productivity, or accumulator species, with lower TE concentration in the biomass but with high biomass production, resulting in high TE removal $[12,13]$. At the other end of the spectrum, phytostabilization aims to manage the risk by decreasing the TE transfer between the different environmental compartments, in particular by decreasing the mobility of TE in the soil and the TE transfer in the plant [14]. For this, excluder plant species can be used, which have low TE transfer to the aboveground shoot biomass [15]. Contrary to conventional remediation techniques, phytotechnologies need to be adapted specifically to the site where they are used, as pedoagronomics parameters and climate conditions can impact TE soil mobility and the species that can be grown [16]. Field experiments need to be performed to confirm the feasibility of the phytotechnology.

Phytoattenuation, also called phytomanagement, combines the aims of the phytotechnologies with the valorization of the contaminated site, which can be obtained via the commercialization of the produced biomass $[12,14,17-19]$. The species to be used should either have similar characteristics to those cultivated on uncontaminated sites in terms of biomass quality and yield or other characteristics specific to the contaminated land or the intended valorization route. For example, a high-Zn biomass content could be searched in the case of the emerging eco-catalysis valorization chain [20]. The produced biomass on a TE-contaminated site could be used in the energy sector $[17,19,21-23]$ and as a feedstock to create high-value products [24-27]. Among the value chains currently studied on contaminated sites in northern Europe, the energy sector seems prominent, as shown by the numerous field experiments set up with, notably, Miscanthus giganteus, Salix sp., Populus sp., or Zea mays [3,4,19,24,28].

Sorghum bicolor L. was domesticated in Africa, where it is cultivated for alimentary purposes. In the world, it is the fifth most-cultivated crop behind wheat, maize, rice, and barley [29]. This species has an excellent water-use efficiency, which makes it droughttolerant [30]. Moreover, this species has a high genetic diversity, which allows the selection of numerous cultivars with various functions (grain, sugar, forage, fiber, and tinctorial), making it highly interesting for nonfood biomass valorization options [31,32]. In addition, its metal-tolerance was evidenced for different cultivars, as reported in studies performed in Italia, Bulgaria, and China on metal-contaminated sites [13,32-37]. In China, a field experiment has been carried out to study and to discuss phytoremediation of $\mathrm{Cd}$-contaminated land with sorghum for providing a safe farming system, notably by the production of bioethanol [32]. Considering all these advantages, the use of Sorghum bicolor L. (Moench) for the phytoattenuation in northern Europe seems promising and, to our knowledge, has not been studied in this context.

This work was conducted on a metal-contaminated sediment landfill site in northern Europe (Hauts-de-France) and aimed to assess the relevance of two sorghum cultivars, Biomass 133 and Trudan Headless, in a phytoattenuation strategy. The first objective was to evaluate the adequacy between the cultivar and the phytotechnology (phytoextraction or phytostabilization) through the study of the impact of the cultivars on the TE soil mobility and their TE accumulation behavior. The second objective was to discuss potential biomass valorization options, with a focus on biogas production, based on cultivation parameters, such as yield and biomass quality of the cultivars.

\section{Materials and Methods}

\subsection{Site Description and Experimental Setup}

A field trial of 1 ha was set up at a former dredged sediment disposal site located in Fresnes-sur-Escaut (Hauts-de-France, France; $50^{\circ} 25^{\prime} 41.1^{\prime \prime} \mathrm{N} 3^{\circ} 35^{\prime} 01.9^{\prime \prime} \mathrm{E}$ ). The disposal site was created in 1978 and received canal sediments until 1989; it was no longer exploited by human activities after this date. The area is characterized by a temperate climate, with a mean temperature between June and September of $18.7^{\circ} \mathrm{C}$ and cumulative precipitation of 
194 mm [38]. In April 2019, an experimental setup was devised to assess different species' applicability for phytoattenuation. Three zones were defined, according to previous studies [39], which have different levels of contamination: area 1, area 2, and area 3 (Figure 1). The study on these three areas allowed the examination of sediment parameters' heterogeneity and their potential impacts on plant performance (agronomic parameters, tolerance, and accumulation potential/accumulator behavior of the different cultivars). To reduce herbivory risk, the plots were protected by a $2 \mathrm{~m}$ high fence, which was buried down by $50 \mathrm{~cm}$.

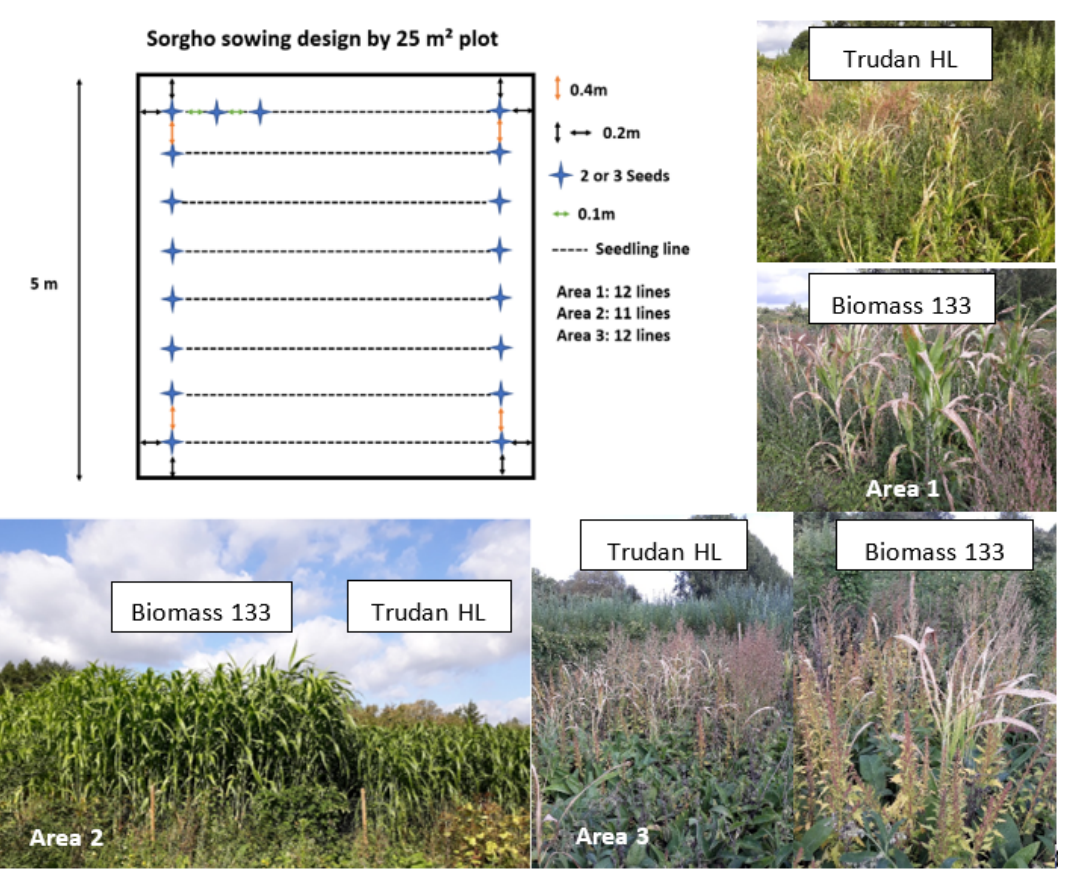

Figure 1. Sorghum sowing design and pictures of the two cultivars on the three areas 99 days after the sowing.

In this study, two sorghum cultivars used in Europe were selected, based on their biogas production potential. Seeds certified for agricultural use were bought at a seed company $[40,41]$. Sorghum biomass 133 is a monoharvest cultivar, characterized by a high production of harvestable biomass ( $20 \mathrm{t} \mathrm{ha}^{-1}$ of dry weight (DW)) 125 days after the sowing. Trudan Headless (HL) sorghum is a multicut cultivar with a total production ranging between 10 and $15 \mathrm{t} \mathrm{ha}^{-1} \mathrm{DW}$. In each area, one plot of $25 \mathrm{~m}^{2}$ was devoted to each cultivar (Figure 1). Before manually sowing (June 2019), tillage, plowing, and weeding were carried out. In order to maximize the number of plants, sowing at a higher density than the one recommended in agriculture (250,000 seeds ha ${ }^{-1}$ and $25 \mathrm{~kg} \mathrm{ha}^{-1}$, for Biomass 133 and Trudan HL, respectively) [40,41] was performed (between 1518 and 1656 seeds for $25 \mathrm{~m}^{2}$, i.e., a sowing density between 600,200 and 662,400 seeds ha ${ }^{-1}$ ). No weed treatment other than mechanical was performed during the experiment, due to the constraints imposed by the sediment site manager.

\subsection{Sediment Sampling and Analysis}

For sediment sampling, the first $20 \mathrm{~cm}$ of sediment depth were collected with a hand auger. The sediment sampling followed two strategies. First, five sediment samples were taken randomly per plot. This was done in May 2019 to obtain the initial state of sediment in the studied areas, i.e., before sowing the plots but after plowing. The second sampling strategy was carried out in September and October 2019, just before the harvest. Ten sediment samples associated with plant samples were taken per plot, leading to a total of 30 samples for each sorghum cultivar (10 samples * 3 areas). Sediment samples were dried at $40{ }^{\circ} \mathrm{C}$ in a forced-air oven until constant weight, ground (Retsch BB51), and sieved to 
$<2 \mathrm{~mm}$. Sediment $\mathrm{pH}$ was measured following the International Standart Organisation (ISO) 10390 (2005). Five grams of sediment were mixed with $25 \mathrm{~mL}$ of distilled water and shaken for $2 \mathrm{~h}$. After $1 \mathrm{~h}$ rest, $\mathrm{pH}$ was measured ( $\mathrm{pH}$ meter Hanna edge). To estimate the plant available fraction of TE, a selective extraction was performed. Ten grams of sediment with $20 \mathrm{~mL}$ of ammonium nitrate $\left(\mathrm{NH}_{4} \mathrm{NO}_{3}, 1 \mathrm{M}\right)$ were shaken for $2 \mathrm{~h}$ [42]. The mixture of sediment and $\mathrm{NH}_{4} \mathrm{NO}_{3}$ was filtered $(0.45 \mu \mathrm{m}$, millipore) and acidified with nitric acid $(69 \%)$ to obtain a $\mathrm{pH}$ of 2.

For each zone, $50 \mathrm{~g}$ per sediment sample was taken and mixed to create a composite per studied zone on which agronomic sediment parameters were measured (Supplemental Table S1). These analyses were subcontracted (Laboratoire Départemental d'Analyses de la Mayenne, La Mayenne, France). Additionally, the composites' TE content was analyzed by digesting a dried (oven, $40{ }^{\circ} \mathrm{C}$ until constant weight) and homogenized sample (250 $\mu \mathrm{m}$, ball mill, Lavallab Pulverisette 6). The digestion consisted of $0.2 \mathrm{~g}$ of sediment mixed with $6 \mathrm{~mL}$ of hydrofluoric acid (HF) (48\%) heated in a microwave digester (Mars Xpress CEM). HF was then neutralized with boric acid (5.5\%). To obtain a $50 \mathrm{~mL}$ solution, the mixture was completed with Milli-Q water and filtered at $0.45 \mu \mathrm{m}$ (hydrophilic Teflon). TE concentrations in digestates were analyzed either by ICP-OES (Agilent 5100) or ICP-MS (Agilent 7500), depending on sediment sample concentrations. One standard reference material was used for analytical quality control (NIST SRM 2710, Montana soil). For all the digestion sets, recoveries were between 1.12 and 1.15 for As, 0.80 and 0.93 for $\mathrm{Cu}, 1.05$ for $\mathrm{Ni}, 0.95$ and 0.98 for $\mathrm{Pb}$, and 0.96 and 1.04 for $\mathrm{Zn}$ in the Montana soil. For $\mathrm{Cd}, \mathrm{Cr}$, and $\mathrm{Sb}$, no recoveries could be calculated; the results obtained from ICP-OES analysis were below the limit of quantification (LoQ).

The extractable and total TE concentrations in the soils allowed us to calculate the \% TE mobility, with $\%$ mobility $=[$ TE] extractable sediment $/[$ TE] total sediment $* 100$.

\subsection{Germination Tests}

The germination rate of both cultivars was performed in minigreenhouses $(41 \mathrm{~cm} \times$ $52 \mathrm{~cm} \times 24 \mathrm{~cm}$ ) and measured after 20 days under controlled conditions (culture chamber, $20{ }^{\circ} \mathrm{C}, 70 \%$ moisture, $12 \mathrm{~h}$ day cycles) with 4 different conditions: control (terreau potager bio Gamm vert) and a composite of sediment per studied area (1,2, and 3), made according to the methodology described in the Section 2.2. The total TE concentration in the sediment of each area are reported in the Table 1. Fifty seeds per cultivar (see Section 2.1 for seed origin) were sown in each condition. One minigreenhouse corresponded to one condition.

\subsection{Plant Sampling and TE Analysis}

The Trudan HL and the Biomass 133 sorghum were entirely harvested in area 2 in September 2019 (105 days of growth) and in October 2019 (131 days of growth), respectively. In addition, on areas 1 and 3, ten samples of both cultivars were collected in September 2019. Before harvest, samples of the aerial parts of sorghum were taken randomly at the same time as sediment samples. As a result, ten samples of sorghum per plot and per zone, i.e., thirty samples of each sorghum cultivar, were collected. Plants were cut at their base using a hand pruner and transported to the laboratory for analysis. The height of each sample of Biomass 133 sorghum was measured for comparison with expected height; for Trudan HL, this measurement was not useful, as this is a multicut cultivar. On the plots in area 2, all the remaining plants were cut with a hand pruner and then gathered and weighed using a portable hand scale to obtain the plot yields of the two cultivars. Plant materials were washed with tap and deionized water before drying $\left(40^{\circ} \mathrm{C}\right.$ until constant weight) and ground to a powder using a blender. In addition, in order to obtain fresh and dry masses, the samples were weighed before washing and grinding. Following this preparation, $0.5 \mathrm{~g}$ of each plant sample was mineralized with $\mathrm{HNO}_{3}(10 \mathrm{~mL}, 69 \%)$ and heated in a microwave digester (Mars Xpress CEM). The solution was then made up to $50 \mathrm{~mL}$ with Milli-Q water and filtered $(0.45 \mu \mathrm{m}$, hydrophilic Teflon). The TE concentrations in the eluates were measured by ICP-OES (Agilent 5100) or ICP-MS (Agilent 7500). One 
standard reference material was used for analytical quality control (Branches and leaves of Bush "NCS DC 73349," NCS Testing Technology, China, http:/ / www.ncsstandard.com, accessed on 5 June 2018). For all the digestion sets, recoveries were 1.38 for As, between 0.96 and 0.99 for $\mathrm{Cu}, 0.71$ for $\mathrm{Ni}$, between 1.03 and 1.05 for $\mathrm{Pb}$, and 1.03 for $\mathrm{Zn}$. No reference values were available for $\mathrm{Cr}$ in the reference material, and the reference value for $\mathrm{Cd}$ was lower than the LoQ.

Table 1. Main physico-chemical properties, total, and $\mathrm{NH}_{4} \mathrm{NO}_{3}$ extractable (\% of total, expressed between parenthesis) concentrations of trace elements (TE) in the sediment of the field site for each area and TE threshold values (S1) for sediment management. TE concentrations are expressed in $\mathrm{mg} \mathrm{kg}^{-1}$ dry sediment (DS). Values are means $\pm \mathrm{SD}$.

\begin{tabular}{|c|c|c|c|c|c|}
\hline \multicolumn{2}{|c|}{ Parameters } & Area 1 & Area 2 & Area 3 & S1 \\
\hline \multicolumn{2}{|c|}{ Clay (\%) } & 7.7 & 10.7 & 11.7 & - \\
\hline \multicolumn{2}{|c|}{ Silt (\%) } & 69 & 70.5 & 78.6 & - \\
\hline \multicolumn{2}{|c|}{ Sand (\%) } & 23.3 & 18.8 & 9.8 & - \\
\hline \multicolumn{2}{|c|}{$\begin{array}{c}\text { Soil texture } \\
\text { (USDA texture triangle) }\end{array}$} & Fine silt & Fine silt & Fine silt & - \\
\hline \multicolumn{2}{|c|}{ Carbon $\left(\mathrm{g} \mathrm{kg}^{-1}\right)$} & 76.3 & 82.4 & 96.8 & - \\
\hline \multicolumn{2}{|c|}{ Organic matter $\left(\mathrm{g} \mathrm{kg}^{-1}\right)$} & 131.3 & 141.7 & 166.5 & - \\
\hline \multicolumn{2}{|c|}{$\mathrm{C} / \mathrm{N}^{*}$} & 28.4 & 28 & 31.5 & - \\
\hline \multicolumn{2}{|c|}{$\mathrm{CEC}^{+}\left(\right.$meq $\left.100 \mathrm{~g}^{-1}\right)$} & 17.6 & 17.9 & 21.2 & - \\
\hline \multicolumn{2}{|c|}{$\mathrm{CaO}^{++} \mathrm{g} \mathrm{kg}^{-1}$} & 11.7 & 11.5 & 12.5 & - \\
\hline \multicolumn{2}{|c|}{$\mathrm{N}$ kjeldahl TNK ${ }^{+++}\left(\mathrm{g} \mathrm{kg}^{-1}\right)$} & 2.69 & 2.94 & 3.07 & - \\
\hline \multicolumn{2}{|c|}{$\begin{array}{l}\text { Phosphorus Olsen } \\
\quad\left(\mathrm{g} \mathrm{kg}^{-1}\right) \mathrm{P}_{2} \mathrm{O}_{5}\end{array}$} & 0.216 & 0.259 & 0.258 & - \\
\hline \multicolumn{2}{|c|}{$\mathrm{pH}-\mathrm{H}_{2} \mathrm{O}$} & 8.08 & 8.06 & 8.12 & - \\
\hline \multirow{7}{*}{$\begin{array}{l}\text { Total TE } \\
\left(\mathrm{mg} \mathrm{kg}^{-1}\right)\end{array}$} & $\mathrm{Zn}$ & $\begin{array}{c}6685 \pm 509 \\
(0.060 \% \pm 0.004)\end{array}$ & $\begin{array}{c}6084 \pm 132 \\
(0.090 \% \pm 0.008)\end{array}$ & $\begin{array}{c}8980 \pm 340 \\
(0.070 \% \pm 0.012)\end{array}$ & 300 \\
\hline & $\mathrm{Pb}$ & $\begin{array}{c}774 \pm 18 \\
(0.007 \% \pm 0.003)\end{array}$ & $\begin{array}{c}592 \pm 12 \\
(0.009 \% \pm 0.003)\end{array}$ & $\begin{array}{c}1043 \pm 12 \\
(0.007 \% \pm 0.006)\end{array}$ & 100 \\
\hline & $\mathrm{Cd}$ & $\begin{array}{c}6.3 \pm 0.1 \\
(0.47 \% \pm 0.07)\end{array}$ & $\begin{array}{c}5.0 \pm 0.1 \\
(0.62 \% \pm 0.08)\end{array}$ & $\begin{array}{c}9.0 \pm 0.1 \\
(0.48 \% \pm 0.12)\end{array}$ & 2 \\
\hline & $\mathrm{Cu}$ & $\begin{array}{c}87.0 \pm 2.3 \\
(0.53 \% \pm 0.07)\end{array}$ & $\begin{array}{c}76.0 \pm 1.5 \\
(0.59 \% \pm 0.09)\end{array}$ & $\begin{array}{c}101.0 \pm 1.3 \\
(0.52 \% \pm 0.09)\end{array}$ & 100 \\
\hline & As & $\begin{array}{c}33.0 \pm 1.0 \\
(0.043 \% \pm 0.004)\end{array}$ & $\begin{array}{c}29.0 \pm 0.1 \\
(0.050 \% \pm 0.008)\end{array}$ & $\begin{array}{c}43.0 \pm 1.2 \\
(0.030 \% \pm 0.007)\end{array}$ & 30 \\
\hline & $\mathrm{Cr}$ & $\begin{array}{c}116 \pm 12 \\
(0.020 \% \pm 0.002)\end{array}$ & $\begin{array}{c}114 \pm 3 \\
(0.040 \% \pm 0.007)\end{array}$ & $\begin{array}{c}100 \pm 4 \\
(0.030 \% \pm 0.004)\end{array}$ & 150 \\
\hline & $\mathrm{Ni}$ & $\begin{array}{c}52 \pm 1 \\
(0.19 \% \pm 0.05)\end{array}$ & $\begin{array}{c}51 \pm 1 \\
(0.21 \% \pm 0.03)\end{array}$ & $\begin{array}{c}53 \pm 1 \\
(0.20 \% \pm 0.04)\end{array}$ & 50 \\
\hline
\end{tabular}

$\mathrm{C} / \mathrm{N}^{*}$ : carbon/nitrogen, $\mathrm{CEC}^{+}$: cationic exchange capacity, $\mathrm{CaO}^{++}$: calcium oxide, $\mathrm{TNK}^{+++}$: total nitrogen kjeldahl.

Using the TE concentrations in plants and total and extractable concentrations in sediment, the bioconcentration factor (BCF) [43] was calculated as follows:

(1) $\mathrm{BCF}$ ext $=[\mathrm{TE}]$ plant $/[\mathrm{TE}]$ sediment extractable

(2) $\mathrm{BCF}$ tot $=[\mathrm{TE}]$ plant $/[\mathrm{TE}]$ sediment total

\subsection{Biogas Production and Energy Value}

The analysis was subcontracted to the laboratory Innolab (Oostkamp, Belgium). For both sorghum cultivars, samples from the biomass harvested on area 2 were sent to 
the laboratory for analysis. Biogas production tests were performed, according to the standard n ${ }^{\circ} 4630$ "Vergärung organischer Stoffe, Substratcharakterisering, Probennahme, Stoffdatenerhebung, Gärversuche," during 50 days at $38^{\circ} \mathrm{C}$ with $3 \mathrm{~L}$ of inoculum; the biogas production and the biogas composition were recorded daily. The results were expressed in both normo $(\mathrm{N}) \mathrm{m}^{3} \mathrm{t}^{-1}$ of fresh matter (FM) and organic dry matter (ODM) for the biogas production. Concerning the biogas composition, they were expressed in percentage $(\%)$ and part per million (ppm) for methane $\left(\mathrm{CH}_{4}\right)$ and hydrogen sulfur $\left(\mathrm{H}_{2} \mathrm{~S}\right)$, respectively. In addition, taking into account the biogas quality and methane energy value given by the laboratory, calculations of potential co-energy production of electricity and heat for the cultivars were also delivered.

\subsection{Statistical Analysis}

The statistical analyses of the values and the boxplots were carried out with the software R 4.0.01 (06/06/2020) and R studio. Before performing the variance homogeneity test (Bartlett test or Fligner-Killeen test), the data's normality (Shapiro test) was checked. Means were compared by ANOVA when the data were parametric and by the KruskalWallis test when they were not. A post hoc test (Tukey Honestly Significant Difference (HSD) test or pairwise $t$-test) was applied when a statistical difference of $5 \%$ was evidenced. To study a potential correlation between variables, a Pearson correlation test was done.

\section{Results and Discussion}

\subsection{Main Physico-Chemical Properties of the Sediments from the Three Studied Areas}

Table 1 presents the initial sediment characterization results for the three areas. Sediment and agronomic parameters results showed homogeneous sediment texture between the three zones (fine silt). Organic matter was in the high range $>40 \mathrm{~g} \mathrm{~kg}^{-1}$ [44], with a carbon/nitrogen $(\mathrm{C} / \mathrm{N})>>10$, probably due to the sediment matrix [29]. Moreover, the $\mathrm{pH}$ was alkaline in the three areas.

For each area, total TE concentrations in sediments were compared to the sediment remediation criterion S1 (Table 1), a parameter for guiding the management of sediments according to their pollution (French Environmental code, article R214-1, Section 3.2.1.0) [45]. Given the total concentrations in each area, $\mathrm{Zn}, \mathrm{Cd}$, and $\mathrm{Pb}$ were above the $\mathrm{S} 1$ values, which confirmed the need to find a management option for these areas, taking into account the pollution. In addition, based on these total concentrations, the areas could be ranked from the least contaminated to the most contaminated, area $2<$ area $1<$ area 3 , which confirmed TE heterogeneity of the sediment and the selection of the three areas.

In the absence of reference for sediments, the extractable TE concentrations obtained with $\mathrm{NH}_{4} \mathrm{NO}_{3}$ were compared to the reference values usually found in soils, following the standard ISO 19730:2008 (E) (As: $0.025 \mu \mathrm{g} \mathrm{g}{ }^{-1}$; Cd: $0.005 \mu \mathrm{g} \mathrm{g}^{-1}$; Cr: $0.01 \mu \mathrm{g} \mathrm{g}^{-1}$; Cu: $0.25 \mu \mathrm{g} \mathrm{g}^{-1}$; Ni: $0.25 \mu \mathrm{g} \mathrm{g}^{-1}$; Pb: $0.02 \mu \mathrm{g} \mathrm{g}^{-1}$; $\mathrm{Zn:} 0.25 \mu \mathrm{g} \mathrm{g}^{-1}$ ) [42]. The extractable concentrations measured for $\mathrm{Zn}, \mathrm{Pb}, \mathrm{Cd}$, and $\mathrm{Cu}$ in all sediment samples were higher than the baseline, suggesting that the solubility of these TE in the contaminated site is higher than that frequently measured in sediment (Table 1). The concentrations found for the other TE were lower than the reference values. Currently, regulation and threshold are based on total TE concentration in risk assessment and do not consider the available fraction; however, this is the fraction interacting with the environment and, therefore, the one with the most harmful effect [11]. In view of total and extractable concentrations, the elements requiring special attention were $\mathrm{Zn}, \mathrm{Pb}, \mathrm{Cd}$, and $\mathrm{Cu}$. Consequently, the following sections focused on these TE.

\subsection{Biomass Yield of Sorghum on the TE-Contaminated Site}

For the cultivar Biomass 133, the germination rates ranged from $72 \%$ in the unpolluted condition to more than $76 \%$ in polluted conditions $(80 \%$ in area $1,76 \%$ in area $2,84 \%$ in area 3). Concerning the cultivar Trudan HL, the rates ranged from $94 \%$ in the unpolluted 
condition to $92 \%$ in area $1,94 \%$ in area 2 , and $84 \%$ in area 3 . These results indicated that high contamination levels did not seem to be a problem concerning sorghum germination.

The dry weight of both cultivars was calculated after sampling plant individuals in the three areas (Table 2). The growth of the Trudan HL was similar on the three areas. Concerning cultivar Biomass 133, its growth in area 3 was the lowest, with a dry weight 15 times lower than in area 2 and 8 times lower than in area 1 (Table $2, p<0.05$ ). The highest growth was thus on the area 2 (Table $2, p>0.05$ ).

Table 2. Average dry weight by plant of the 2 sorghum cultivars sampled at harvest for the 3 areas (10 samples by area, mean $+\mathrm{SD}$ ). Significant differences between conditions are indicated by different letters at the level of $\alpha=0.05$.

\begin{tabular}{ccc}
\hline & Area & Average Dry Weight Per Plant (g) \\
\hline \multirow{3}{*}{ Trudan Headless } & 1 & $16 \pm 9^{\mathrm{a}}$ \\
\cline { 2 - 3 } & 2 & $43 \pm 16^{\mathrm{a}}$ \\
\cline { 2 - 3 } Biomass 133 & 3 & $16 \pm 8^{\mathrm{a}}$ \\
\cline { 2 - 3 } & 1 & $125 \pm 88^{\mathrm{b}}$ \\
\cline { 2 - 3 } & 2 & $247 \pm 98^{\mathrm{c}}$ \\
\hline
\end{tabular}

Since area 2 presented the lowest metal contamination, a direct and negative correlation could be drawn between yield and contamination. However, the successful germination and plant growth confirmed the metal-tolerance of both cultivars, which is in agreement with other studies reporting that this characteristic is widespread in this species $[13,33,34,46]$. Therefore, in addition to the pollution level of the different areas, other factors could explain the differences in dry weight observed between the areas, such as competition with plant colonizers. As observed in Figure 1, some plants naturally colonized areas 1 and 3, resulting in a competition between these indigenous species and the sorghum. From a practical point of view, this confirms that a mechanical weeding, at least at the beginning of the culture, is necessary to favor the sorghums' growth and ensure its sustainable implantation [47].

The biomass yields per hectare of the two sorghums are reported in Table 3. They were calculated in area 2, from plots of $25 \mathrm{~m}^{2}$, where all biomass was harvested and extrapolated per hectare. A strong correlation between dry matter (DM) and fresh matter (FM) $(r=0.99, p<0.05)$ was observed, which decreased the uncertainty of the DM extrapolation. The extrapolated yields for the two cultivars were comparable to those obtained on an agricultural site under optimal conditions $[40,41]$. This result suggested that both cultivars were adapted to the climatic conditions found in the Hauts-de-France region and that the contamination did not negatively affect biomass production.

Indeed, the extreme temperature of $41.5^{\circ} \mathrm{C}$ and the water deficiency that occurred one month after field sowing (not shown) did not reduce the growth of both cultivars, which agrees with [48], who showed that reduced irrigation or the absence of irrigation has limited impact on the yield of sorghum. In the context of climate change, in which high temperatures and drought periods are expected to increase, these crop cultivars could represent an alternative to the current ones, such as maize, in this region. 
Table 3. Biomass yield, growth duration, and height of sorghum in area 2, FM: fresh matter, DM: dry matter.

\begin{tabular}{|c|c|c|c|c|c|}
\hline Area 2 & Yield $\left(\mathrm{kg} / 25 \mathrm{~m}^{2}\right)$ FM & Yield (t ha $\left.{ }^{-1}\right)$ FM & Yield (t ha- $\left.{ }^{-1}\right) \mathrm{DM}$ & $\begin{array}{c}\text { Duration of } \\
\text { Growth (Day) }\end{array}$ & Height (m) \\
\hline $\begin{array}{l}\text { Sorghum Biomass } \\
133\end{array}$ & 137.43 & 54.97 & 21.75 & 131 & $3.39( \pm 0.21)$ \\
\hline $\begin{array}{c}\text { Reference Biomass } \\
133[40]\end{array}$ & - & - & 20.7 & $105-125$ & 3.5 \\
\hline $\begin{array}{c}\text { Sorghum Trudan } \\
\text { HL }\end{array}$ & 80.97 & 32.38 & 9.85 & 105 & - \\
\hline $\begin{array}{c}\text { Reference Trudan } \\
\text { HL [41] }\end{array}$ & - & - & $10-15$ & $\begin{array}{l}60 \text { first cut and } 30 \mathrm{~s} \\
\text { cut }(90)\end{array}$ & - \\
\hline
\end{tabular}

\subsection{Sorghum Metal Transfer on the TE-Contaminated Site and Biomass Quality}

\subsubsection{Sorghum Effect on the TE Extractable Fraction}

The $\mathrm{pH}$ values measured on all plots, throughout the study, were slightly alkaline, situated around 8 (Supplementary Figure S1), even though the two sorghum cultivars seemed to slightly lower the sediment $\mathrm{pH}(p<0.05)$ as a consequence of $\mathrm{H}^{+}$excretion by the root system during the absorption of nutrients $\left(\mathrm{NH}_{4}{ }^{+}\right)$[49].

Before sorghum cultivation, the average extractable $\mathrm{Cd}, \mathrm{Cu}, \mathrm{Pb}$, and $\mathrm{Zn}$ concentrations measured in the sediment were $0.03,0.48,0.06$, and $5.16 \mu \mathrm{g} \mathrm{g}^{-1}$ dry sediment (DS), respectively. These concentrations were between 2.5 to 27 times higher than the reference value reported in the standard ISO 19730:2008 (E) (Figure 2A,B) [42]. The culture of Biomass 133 did not modify the extractable $\mathrm{Zn}$ concentrations measured in the sediment in areas 1 and 3 (Figure 2A), while a slightly negative effect of the cultivar was evidenced in area $2(p<0.05)$, with an increase in the extractable $\mathrm{Zn}$ concentration (Figure 2A). For $\mathrm{Cd}$, a positive effect of the cultivar was observed in area 3 , the area with the highest extractable concentration (Figure 2A). Concerning the cultivar Trudan HL, an adverse effect of the cultivar was only found on area 3 for $\mathrm{Zn}$ and $\mathrm{Cd}$, with extractable concentrations being higher at harvest than at the beginning (Figure 2B, $p<0.05$ ).

In contrast to $\mathrm{Zn}$ and $\mathrm{Cd}$, extractable concentrations of $\mathrm{Pb}$ and $\mathrm{Cu}$ (Figure 2A, $\mathrm{B}$ ) did not show a statistical difference $(p>0.05)$ in any of the studied areas for either of the cultivars, which could be related to their closer value to the references even before cultivation, rather than to a selective effect of the cultivars. The absence of a clear effect of the cultivars on metal extractability in the sediment, according to the areas and TE, indicated that both cultivars had no or a small impact on this parameter in our experimental conditions.

The percentage (\%) of mobile TE calculated as extractable concentrations over total concentrations is evidenced by the following order of mobility, $\mathrm{Pb}<\mathrm{Zn}<\mathrm{Cd}<\mathrm{Cu}$, irrespective to the cultivars and the areas (Supplementary Table S2). Negative correlations between $\mathrm{pH}$ and TE extractable concentrations were demonstrated (Cd: $p<0.001, \mathrm{r}=-0.36 ; \mathrm{Cu}$ : $p<0.05, \mathrm{r}=-0.23 ; \mathrm{Pb}: p<0.05, \mathrm{r}=-0.22 ; \mathrm{Zn}: p<0.001, \mathrm{r}=-0.60)$, indicating that a $\mathrm{pH}$ decrease could increase the TE extractable concentration and explain the small significant variations found for some TEs.

With regard to sediment deposit management, and in the particular case of field studies with high sediment TE contamination, it could be advised to maintain the $\mathrm{pH}$ around 8 to minimize the TE mobility in the sediment and limit the TE transfer in the environment $[28,50]$. To reduce extractable concentrations, especially for $\mathrm{Cd}$ and $\mathrm{Zn}$, coupling sorghum to an amendment that would maintain $\mathrm{pH}$ at 8 could achieve this objective. The addition of an alkaline amendment that does not modify the sediment $\mathrm{pH}$, like biochar, could also reduce the $\mathrm{Cd}$ extractable concentration by the creation of a stable complex with iron or manganese oxides or by adsorption [51,52]. As sorghum is known to be mycorrhizable, the addition of an arbuscular mycorrhiza fungi (AMF) inoculum could 
favor the decrease of TE mobility, either by excretion by the hyphae of glomalin able to bind with soluble TE or by adsorption and storage in hyphae of the soluble fraction [46,53-55].
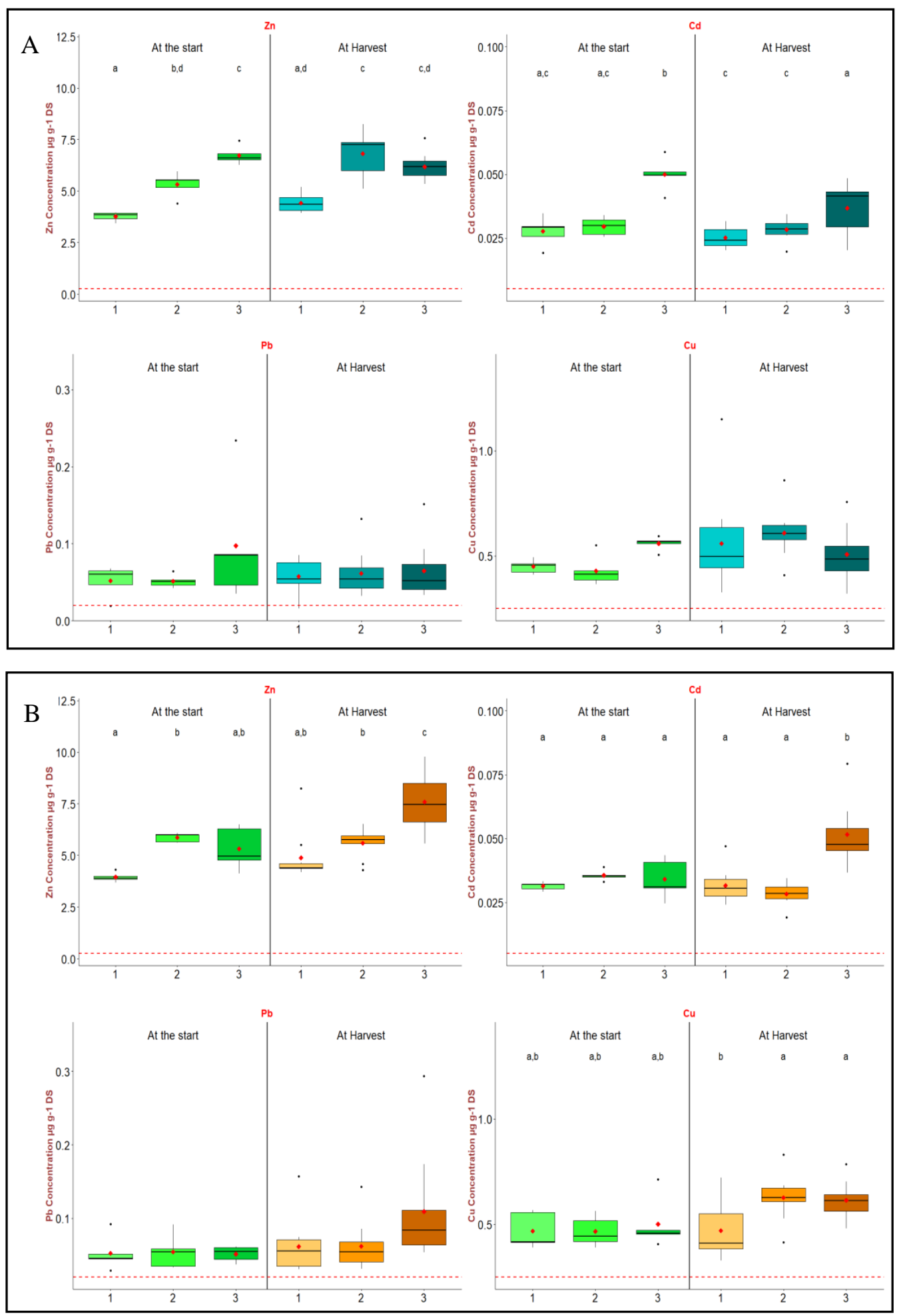

Figure 2. Sediment $\mathrm{NH}_{4} \mathrm{NO}_{3}$ extractable concentration of $\mathrm{Zn}, \mathrm{Cd}, \mathrm{Pb}$, and $\mathrm{Cu}$ at the start (green), at harvest of sorghum Biomass 133 (blue, A), and at harvest of sorghum Trudan Headless (orange, B) for the 3 areas $(1=$ area $1,2=$ area 2, $3=$ area 3$)$. The box plots indicate the median and the 25 and the 75 percentiles; red diamond = mean; the dotted red line corresponds to the value references noticed in the ISO 19730:2008 (E). Significant differences between conditions are indicated by different letters at the level of $\alpha=0.05$. 


\subsubsection{TE Transfer in the Aerial Biomass of the Sorghum}

In general, Trudan HL had higher TE content than Biomass 133, even though this varied between areas and specific TEs (Figure 3). In addition, according to Figure 3, area 2 resulted in the lowest TE accumulation, regardless of the cultivar and the TE, which correlates well with its lowest level of contamination. A positive correlation between TE extractable concentrations and biomass accumulation was also observed $(p<0.05)$. However, this is not true for area 1, which had the lowest extractable TE concentrations but high TE contents in the biomass. The link between dry weight and TE concentrations, especially $\mathrm{Zn}$ and $\mathrm{Cd}$, might suggest that the lowest TE contents were obtained at the end of the growth period, where the biomass was the highest. To confirm this assumption, additional experiments should be performed to follow the composition of different cultivars at different times of growth, in order to investigate this dilution effect.
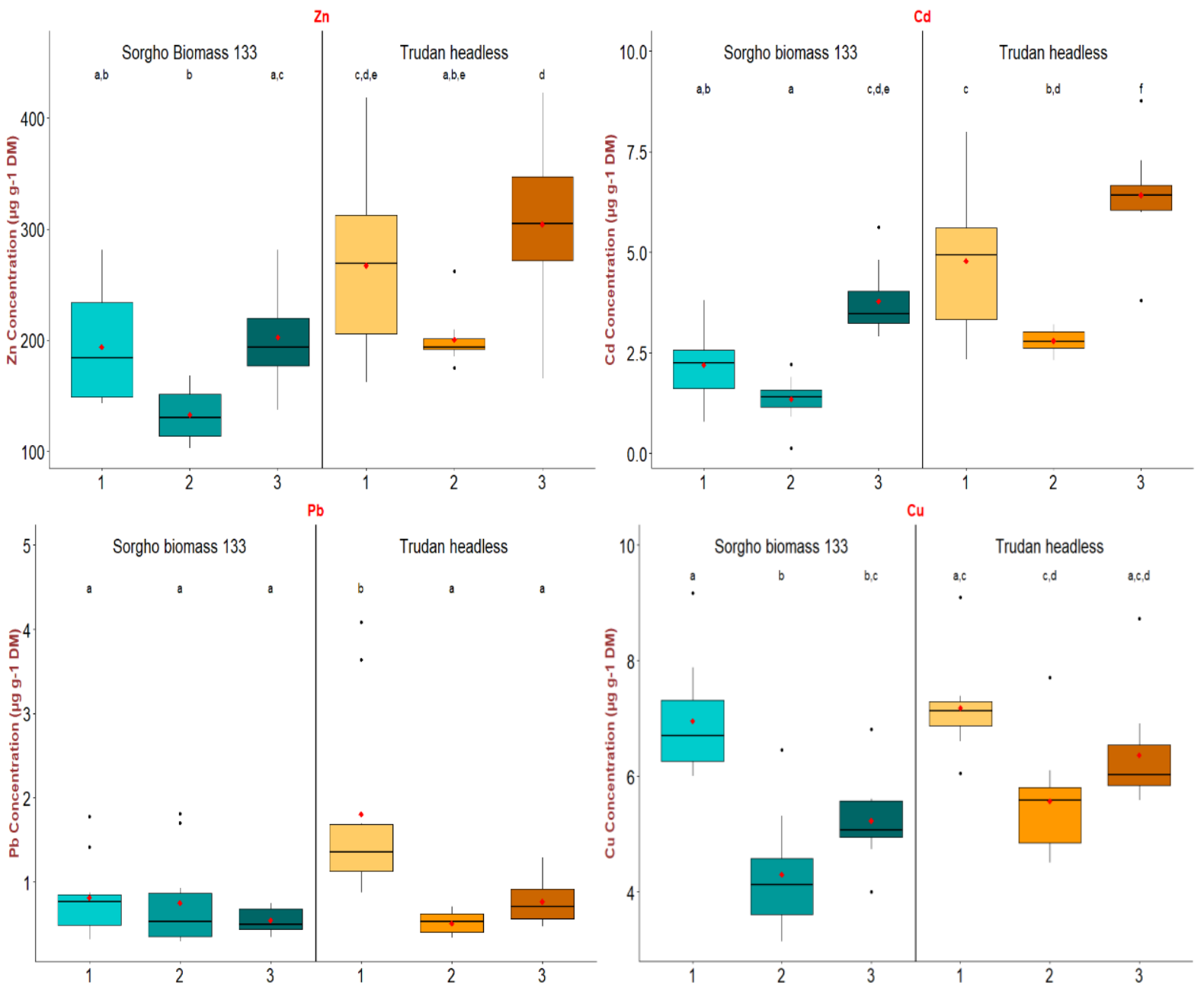

Figure 3. Concentrations of $\mathrm{Zn}, \mathrm{Cd}, \mathrm{Pb}$, and $\mathrm{Cu}$ in the sorghum Biomass 133 (blue) and the sorghum Trudan Headless (orange) in the three areas $(1=$ area $1,2=$ area 2, $3=$ area 3$)$. The box plots indicate the median and the 25 and 75 percentiles; red diamond $=$ mean. Significant differences between conditions are indicated by different letters at the level of $\alpha=0.05$.

When comparing with other studies, the average $\mathrm{Zn}$ concentrations in the biomass of the two cultivars were between 2.6 and 6 times higher than concentrations found in sorghum grown in a culture chamber with artificially contaminated soil $\left(50 \mu \mathrm{g} \mathrm{g}^{-1}\right)$ [56]. This can be possibly related to the different levels of contamination between our study and Epelde et al., as their maximum $\mathrm{Zn}$ concentration was six to nine times lower than the ones found in the sediments of the present study. Regarding Cd, a field plot experiment on TE-contaminated soil [13] found concentrations in sweet sorghum of the same order as in 
our study. Conversely, [33] measured 10 to 20 times lower $\mathrm{Cd}$ concentrations in sorghum biomass $\left(0.2 \mu \mathrm{g} \mathrm{g}^{-1}\right)$ after 40 days of growth. The different concentrations reported in these studies could be explained by the use of different cultivars, the different growth duration before harvest, or a different extractable fraction in sediment. $\mathrm{Pb}$ concentration in the leaves of three sweet sorghum cultivated on a contaminated site ranged from 37 to $42 \mu \mathrm{g} \mathrm{g}^{-1}$ of DM [13]. In our study, Pb concentrations ( $<2 \mu \mathrm{g} \mathrm{g}^{-1}$, Figure 3$)$ were much lower than those reported in [13] and in other Poaceae, such as barley $\left(8 \mu \mathrm{g} \mathrm{g}^{-1}\right)$, cultivated on uncontaminated site [50]. Regarding $\mathrm{Cu}$, [34] showed, for different cultivars of sorghum, that concentrations in the leaves were of 3 and $4.5 \mu \mathrm{g} \mathrm{g}^{-1}$ on uncontaminated and contaminated soil, respectively. Concentrations found in our study were similar, indicating that $\mathrm{Cu}$ concentrations could be considered normal for the two cultivars.

The bioconcentration factors (BCF) were calculated for the two cultivars for the different areas and TEs (Supplementary Table S2). The highest BCFs were found for $\mathrm{Cd}$, irrespective of cultivar or area, varying from 0.26 to 0.43 for Biomass 133 and 0.53 to 0.76 for Trudan HL. All factors were below 1, characterizing an excluder behavior, which is one trend required in a phytostabilization strategy.

\subsection{Valorization Options for Sorghum}

\subsubsection{Biogas and Energy Production}

The biogas tests $(n=2)$ presented in Table 4 for both cultivars were performed on biomass collected from area 2 , since, in this area, growth and yield were similar to those expected on uncontaminated agricultural soil (Table 3).

Table 4. Average biogas production ( $n=2, \pm S D)$, biogas quality, and energy production for the two cultivars of sorghum cultivated on the area 2 .

\begin{tabular}{|c|c|c|}
\hline & Sorghum Biomass 133 & Sorghum Trudan HL \\
\hline Biogas production $\left(\mathrm{Nm}^{3} \mathrm{t}^{-1} \mathrm{FM}\right)$ & $205 \pm 2$ & $325 \pm 11$ \\
\hline Biogas production $\left(\mathrm{Nm}^{3} \mathrm{t}^{-1} \mathrm{ODM}\right)$ & $329 \pm 20$ & $398 \pm 7$ \\
\hline Average $\mathrm{CH}_{4}$ level \% & 53 & 56 \\
\hline Average $\mathrm{H}_{2} \mathrm{~S}$ level ppm & 22 & 18 \\
\hline Electricity production ( $\mathrm{kWhe} \mathrm{t}^{-1} \mathrm{FM}, 41 \%$ efficiency) & $439 \pm 2$ & $737 \pm 16$ \\
\hline Heat production (kWht $\mathrm{t}^{-1} \mathrm{FM}, 44 \%$ efficiency) & $469 \pm 2$ & $787 \pm 18$ \\
\hline Potential $\mathrm{CH}_{4}$ production $\left(\mathrm{Nm}^{3} \mathrm{CH}_{4} \mathrm{ha}^{-1}\right)$ & 5924 & 5862 \\
\hline
\end{tabular}

The biogas productivity and yield obtained with each of the two cultivars of sorghum were different. Concerning Trudan HL, the time to obtain $91 \%$ of the total biogas production was between 9 and 16 days. For Biomass 133, this time was between 21 and 25 days. Additionally, the maximum biogas and, more specifically, the maximum biomethane production $\left(\mathrm{Nm}^{3} \mathrm{~T}^{-1} \mathrm{FM}\right)$ obtained with Trudan HL was $1.2{ }^{*}$ higher than with Biomass 133. Interestingly, Barbanti et al. [57] found the opposite, with Biomass 133 resulting in a slightly higher biomethane production than Trudan HL, when cultivated in uncontaminated soil, indicating that this is not inherent to the cultivars and is probably more related to the cultivation conditions. In that study, biomethane yields of 268 and $251 \mathrm{Nm}^{3} \mathrm{~T}^{-1} \mathrm{ODM}$ were found for Biomass 133 and Trudan HL, respectively, which are higher than the values found in the present study of 174 and $223 \mathrm{Nm}^{3} \mathrm{~T}^{-1}$ ODM, respectively. These lower biomethane yields may be an effect of the presence of TE in the biomass used in the present study or simply the result of the variation in biomass composition, due to different cultivation conditions between the two studies. Since Trudan HL resulted in the highest biogas yield while also having the higher TE content in its biomass, it seems the latter explanation is more adequate, indicating that TE might not have had a detrimental effect on biogas production. Nevertheless, more investigations are needed for comparing sorghum grown on contaminated and uncontaminated locations with similar soil texture, nutrient availability, and climatic conditions, to allow for a proper assessment of the effect of TE presence in the biogas yield of sorghum biomass issued from phytoattenuation. 
Based on the obtained yields, Trudan HL seemed more suitable for biogas production than the other cultivar. Nevertheless, the total biogas production per hectare for each cultivar was also used for comparison, as this can be a more important parameter for choosing the best cultivar from an agricultural point of view. The biogas production was 11,241 and $10,524 \mathrm{Nm}^{3} \mathrm{ha}^{-1}$, which led to a methane production of 5924 and $5862 \mathrm{Nm}^{3} \mathrm{CH}_{4}$ per hectare (Table 4) for the cultivars Biomass 133 and Trudan HL, respectively. These values are similar to the ones reported for other crops, such as sunflower, sugarbeet, and corn [58,59], and result in Biomass 133 being the most suited crop for biogas production, due to its higher biomass yield, which compensates its slightly lower biogas production potential.

On an energy basis, the total production of biogas from Biomass 133 could cogenerate each year around 24,000 kWhe ha ${ }^{-1}$ of electricity and 25,000 kWht ha ${ }^{-1}$ of heat (Table 4). This co-energy production was similar to the one obtained with silage maize [19], suggesting that Biomass 133 might be an interesting alternative to maize for the production of biogas and renewable energy in Northwest Europe. The Flemish regulation has set threshold values concerning the TE concentration in the biomass used for bioenergy production (Cd: $6 \mu \mathrm{g} \mathrm{g}^{-1}$; Pb: $300 \mu \mathrm{g} \mathrm{g}^{-1}$; Zn $900 \mu \mathrm{g} \mathrm{g}^{-1}$ ) [19]. The observed values in the sorghum biomass in our experiment were, therefore, lower than the Flemish regulation.

To ensure the viability of the biogas value chain with sorghum cultivated on contaminated sites, the valorization of the digestate should be considered. The digestate might be used as a soil improver or as a fertilizing product if it complies with the TE concentration thresholds set in the regulation on fertilizer (Cd $2 \mu \mathrm{g} \mathrm{g}^{-1} ; \mathrm{Cu} 300 \mu \mathrm{g} \mathrm{g}^{-1} ; \mathrm{Pb} 120 \mu \mathrm{g} \mathrm{g}^{-1}$; $\left.\mathrm{Zn} 800 \mu \mathrm{g} \mathrm{g}^{-1}\right)$ [60]. Based on the TE concentrations in the Biomass $133\left(1.6 \mu \mathrm{g} \mathrm{g}^{-1}\right.$ in Figure 3 , area 2 ) and due to dry matter loss occurring during the process, we could estimate that the TE concentrations in the produced digestate might exceed the threshold value for $\mathrm{Cd}$. Indeed, based on a $48 \%$ dry matter loss, the calculated Cd concentration would be $2.4 \mu^{\mathrm{g} \mathrm{g}^{-1}}$ [61], which suggests that $\mathrm{Cd}$ could limit the digestate valorization in this case. Moreover, applying the digestate directly to the soil without any TE removal pretreatment would just redistribute the contamination instead of remediating it. Therefore, the recovery of TE from digestate before soil application should be envisaged when anaerobic digestion is proposed as a valorization route for phytoattenuation biomass and should be the subject of future investigations.

\subsubsection{Other Biomass Valorization Options}

Due to the different compositions of the two cultivars, other biomass valorization options than biogas production could be considered, such as biofortification [62-65] and bioethanol production $[35,66,67]$. The sorghum cultivar Trudan HL could be a relevant candidate for the first. Indeed, it is a forage cultivar currently used for ruminant animal feeding [41], and the $\mathrm{Zn}$ concentration in the used contaminated field was four to six times higher than the physiological value of these animals [56]. Nevertheless, this Znenriched biomass could complement the animal diet only if other TE in the biomass would comply with the threshold values set in the directive 2002/32/EC (2002) on undesirable substances in animal feed [68]. Contrary to $\mathrm{Pb}, \mathrm{Cd}$ could limit this use in biofortification, as $\mathrm{Cd}$ concentrations were at least 2.6 times higher than the threshold set in the directive ( $1 \mu \mathrm{g} \mathrm{g}^{-1} 12 \%$ of water). To avoid any limitation, it could be advisable to cultivate the sorghum cultivar Trudan HL on a soil that does not contain Cd or to reduce the mobility of $\mathrm{Cd}$ in the soil to avoid any soil-plant transfer.

On the other hand, the sorghum cultivar Biomass 133 is a fiber cultivar with a high content in lignocellulose and high biomass yield, which makes it a relevant option for bioethanol production [67]. Six sorghum cultivars were successfully tested to produce second-generation bioethanol from the degradation of cellulose and hemicellulose to produce fermentable sugars [67]. The study evidenced that the most suitable cultivars were those with low lignin content, in order to avoid the decrease of the fermentation yield. In another study, it was shown that the biomass of a sorghum cultivated on a TEcontaminated site could produce bioethanol free of metal, whereas the majority of TE, in 
particular $\mathrm{Cd}$ and $\mathrm{Zn}$, were found in the remaining phase of the production process [66]. From these results, it could be assumed that the cultivar Biomass 133 could be relevant for the production of ethanol.

\subsection{Sorghum Cultivar Adequation as a Phytoattenuation Option}

The phytoattenuation of TE-contaminated sites with relevant plant species is based on two necessary components, the phytotechnology on one hand and a viable biomass valorization option on the other hand $[14,18,19]$. Based on biogas production results, the two cultivars could be used for this valorization. According to results, both sorghum cultivars were considered as TE excluders. To be used in a phytostabilisation strategy, a soil amendment should be required in order to reach the second objective of phytostabilization, i.e., decreasing the TE extractable fraction.

The phytoextraction capacity was assessed for the two cultivars (Table 5). Based on these results, a low phytoextraction capacity could be expected. Overall, the most exported element for both cultivars was $\mathrm{Zn}$, followed to a lesser extent by $\mathrm{Cu}, \mathrm{Cd}$, and $\mathrm{Pb}$. These results are in agreement with those previously reported $[13,33]$ and suggest that the cultivar Biomass 133 could only be potentially used for the phytoextraction of $\mathrm{Zn}$, due to its high biomass yield.

Table 5. Annual $\mathrm{Cd}, \mathrm{Cu}, \mathrm{Pb}$, and $\mathrm{Zn}$ removal for the two cultivars after the biomass harvest.

\begin{tabular}{|c|c|c|c|c|}
\hline Area 2 & $\begin{array}{l}\text { Cd Removal } \\
\left(\mathrm{kg} \mathrm{ha}^{-1} \mathrm{y}^{-1}\right)\end{array}$ & $\begin{array}{c}\text { Cu Removal } \\
\left(\mathrm{kg} \mathrm{ha}^{-1} \mathrm{y}^{-1}\right)\end{array}$ & $\begin{array}{c}\text { Pb Removal } \\
\left(\mathrm{kg} \mathrm{ha}^{-1} \mathrm{y}^{-1}\right)\end{array}$ & $\begin{array}{l}\text { Zn Removal } \\
\left(\mathrm{kg} \mathrm{ha}^{-1} \mathrm{y}^{-1}\right)\end{array}$ \\
\hline Sorghum Biomass 133 & 0.0292 & 0.0935 & 0.0163 & 2.888 \\
\hline Sorghum Trudan HL & 0.0275 & 0.0549 & 0.0050 & 1.973 \\
\hline
\end{tabular}

In our case, TE risk management and the development of a value chain with an income for the site owner would become the main objective. The long, required cleanup time or the fact that TE are not remediated in the case of aided phytostabilization could thus be compensated by this benefit. As discussed for maize and Miscanthus floridulus [17,19], phytoattenuation could be relevant for these cultivars, especially Biomass 133, if the TE remediation of the site is not the main aim.

\section{Conclusions and Perspectives}

To our knowledge, this study is the first to report results on the possible use of sorghum in the phytoattenuation of a TE-contaminated site in northern France. As reported for other cultivars, we demonstrated tolerance of both cultivars to high levels of TE pollution in field conditions and, consequently, their relevance in a phytotechnology strategy. Our study pointed out promising valorization options for biomass cultivated on a TE-contaminated site, such as biogas production. Even if both investigated sorghum cultivars presented an excluder behavior concerning $\mathrm{TE}$, the $\mathrm{Cd}$ concentration measured in their biomass could be a limiting factor for valorization. Finally, the results of the growth parameters of the two sorghum cultivars showed that, irrespective of the site pollution, the pedo-climatic conditions of northern France are suitable for their development.

Additional studies to reduce the $\mathrm{Cd}$ transfer in the plant should be performed to facilitate biomass valorization and to confirm the use of sorghum as a species adapted for phytoattenuation, notably cultivar Biomass 133. Further studies should be realized to ensure the suitability of these cultivars in the climate change context. Moreover, the phytoattenuation with annual crops, such as sorghum, could be considered as a local resource at a territory scale and could be included in a sustainable phytoattenuation strategy. 
Supplementary Materials: The following are available online at https://www.mdpi.com/article/10 .3390/app11083471/s1.

Author Contributions: Conceptualization, A.P. (Alexandre Perlein) and V.B.; methodology, V.B., A.P. (Alexandre Perlein), and A.P. (Arnaud Papin); formal analysis, A.P. (Alexandre Perlein) and O.D.; investigation, A.P. (Alexandre Perlein) and V.B.; resources, A.P. (Arnaud Papin) and R.G.; data curation, A.P. (Alexandre Perlein) and O.D.; writing-original draft preparation, A.P. (Alexandre Perlein); writing-review and editing, V.B., M.F.d.S., E.M., R.G. and I.Z.; visualization, A.P. (Alexandre Perlein) and O.D.; supervision, V.B., E.M., M.F.d.S. and R.G.; project administration, V.B., R.G. and E.M.; funding acquisition, V.B., R.G. and E.M. All authors have read and agreed to the published version of the manuscript.

Funding: This research was cofunded by the New-C-Land Project (Interreg France-WallonieVlaanderen, with the support of the European Regional Development Fund, grant number:1.2.294), the OVAM, the Province WestFlanders and the Walloon Region.

Institutional Review Board Statement: Not applicable.

Informed Consent Statement: Not applicable.

Acknowledgments: The authors thank Voies Navigables de France, which provided access to the field site. The authors are also grateful to Samuel Teillaud, Fabrice Richez, Yohann Baillon, and Farid Ait-Ben-Ahmad for their technical contribution during the sampling campaigns and chemical analyses. The seeds of sorghum were kindly provided by semencesdeprovence.com. We thank the Interreg Project New-C-Land, who permitted the field experiment and the writing of this paper. We thank the anonymous reviewer for their comments, which greatly helped us to improve the manuscript.

Conflicts of Interest: The authors declare no conflict of interest. The funders had no role in the design of the study; in the collection, analyses, or interpretation of data; in the writing of the manuscript; or in the decision to publish the results.

\section{References}

1. Su, C.; Jiang, L.; Zhang, W. A review on heavy metal contamination in the soil worldwide: Situation, impact and remediation techniques. Environ. Skept. Crit. 2014, 3, $24-38$.

2. Sterckeman, T.; Douay, F.; Proix, N.; Fourrier, H.; Perdrix, E. Assessment of the contaminations of cultivated soils eighteen trace elements around smelters in the north of France. Water Air Soil Pollut. 2002, 135, 173-194. [CrossRef]

3. Nsanganwimana, F.; Pourrut, B.; Waterlot, C.; Louvel, B.; Bidar, G.; Labidin, S.; Fontaine, J.; Muchembled, J.; Lounès-Hadj Sahraoui, A.; Fourrier, H.; et al. Metal accumulation and shoot yield of Miscanthus x giganteus growing in contaminated agricultural soils: Insight into agronomic practices. Agric. Ecosyst. Environ. 2015, 213, 61-71. [CrossRef]

4. Witters, N.; Van Slycken, S.; Ruttens, A.; Adriaensen, K.; Meers, E.; Meiresonne, L.; Tack, F.M.G.; Thewys, T.; Laes, E.; Vangronsveld, J. Short-Rotation Coppice of Willow for Phytoremediation of a Metal-Contaminated Agricultural Area: A Sustainability Assessment. BioEnergy Res. 2009, 2, 144-152. [CrossRef]

5. Ali, H.; Khan, E.; Sajad, M.A. Phytoremediation of heavy metals-Concepts and applications (Review). Chemosphere 2013, 91, 869-881. [CrossRef] [PubMed]

6. Gong, Y.; Zhao, D.; Wang, Q. An overview of field-scale studies on remediation of soil contaminated with heavy metals and metalloids: Technical progress over the last decade. Water Res. 2018, 147, 440-460. [CrossRef]

7. Cundy, A.B.; Bardos, R.P.; Puschenreiter, M.; Menchn, M.; Bert, V.; Friesl-Hanl, W.; Müller, I.; Li, X.N.; Weyens, N.; Witters, N.; et al. Brownfields to green fields: Realising wider benefits from practical contaminant phytomanagement strategies. J. Environ. Manag. 2016, 184, 67-77. [CrossRef]

8. Kidd, P.; Mench, M.; Álvarez-López, V.; Bert, V.; Dimitriou, I.; Friesl-Hanl, W.; Herzig, R.; Janssen, J.O.; Kolbas, A.; Müller, I.; et al. Agronomic Practices for improving gentle remediation of trace element-contaminated soils. Int. J. Phytoremediation 2015, 17, 1005-1037. [CrossRef] [PubMed]

9. Kumpiene, J.; Bert, V.; Dimitriou, I.; Eriksson, J.; Friesl-Hanl, W.; Galazka, R.; Herzig, R.; Janssen, J.; Kidd, P.; Mench, M.; et al. Selecting chemical and ecotoxicological test batteries for risk assessment of trace element-contaminated soils (phyto)managed by gentle remediation options (GRO). Sci. Total Environ. 2014, 496, 510-522. [CrossRef]

10. Conesa, H.M.; Evangelou, M.W.H.; Robinson, B.H.; Schulin, R. A Critical View of Current State of Phytotechnologies to Remediate Soils: Still a Promising Tool? Sci. World J. 2012, 2012. [CrossRef]

11. Tangahu, B.V.; Abdullah, S.R.S.; Basri, H.; Idris, M.; Anuar, N.; Mukhlisin, M. A review on Heavy Metals (As, Pb, and Hg) Uptake by Plants through Phytoremediation. Int. J. Chem. Eng. 2011, 2011. [CrossRef]

12. Burges, A.; Alkorta, I.; Epelde, L.; Garbisu, C. From phytoremediation of soil contaminants to phytomanagement of ecosystem services in metal contaminated sites. Int. J. Phytoremediation 2018, 20, 384-397. [CrossRef] 
13. Zhuang, P.; Shu, W.; Li, Z.; Liao, B.; Li, J.; Shao, J. Removal of metals by sorghum plant from contaminated land. J. Environ. Sci. 2009, 21, 1432-1437. [CrossRef]

14. .Robinson, B.H.; Banuelos, G.; Conesa, H.M.; Evangelou, M.W.; Schulin, R. The phytomanagement of Trace Elements in soil. Crit. Rev. Plant Sci. 2009, 28, 140-166. [CrossRef]

15. Garbisu, C.; Alkorta, I.; Kidd, P.; Epelde, L.; Mench, M. Keep and promote biodiversity at polluted sites under phytomanagement. Environ. Sci. Pollut. Res. 2020, 27, 44820-44834. [CrossRef] [PubMed]

16. Zine, H.; Midhat, L.; Hakkou, R.; El Adnani, M.; Ouhammou, A. Guidelines for a phytomanagement plan by the phytostabilization of mining wastes. Sci. Afr. 2020, 10, 2468-2476.

17. Cheng, S.F.; Huang, C.Y.; Chen, K.L.; Lin, S.C.; Lin, Y.C. Phytoattenuation of lead-contaminated agricultural land using Miscanthus floridulus-An in situ case study. Desalination Water Treat. 2016, 57, 7773-7779. [CrossRef]

18. Evangelou, M.W.H.; Deram, A. Phytomanagement: A Realistic Approach to Soil remediating Phytotechnologies with New Challenges for Plant Science. Int. J. Plant Biol. Res. 2014, 2, 1023.

19. Meers, E.; Van Slycken, S.; Adriaensen, K.; Ruttens, A.; Vangronsveld, J.; Du Laing, G.; Witters, N.; Thewys, T.; Tack, F.M.G. The use of bio-energy crops (Zea mays) for 'phytoattenuation' of heavy metals on moderately contaminated soils: A field experiment. Chemosphere 2010, 78, 35-41. [CrossRef]

20. Deyris, P.A.; Bert, V.; Diliberto, S.; Boulanger, C.; Petit, E.; Legrand, Y.M.; Grison, C. Biosourced polymetallic catalysis: A surprising ans efficient means to promote the knoevenagel condensation. Front. Chem. 2018, 6, 6-48. [CrossRef] [PubMed]

21. Pogrzeba, M.; Krzyżak, J.; Rusinowski, S.; McCalmont, J.P.; Jensen, E. Energy Crop at Heavy Metal-Contaminated Arable Land as an Alternative for Food and Feed Production: Biomass Quantity and Quality. In Plant Metallomics and Functional Omics; Sablok, G., Ed.; Springer: Cham, Swizrland, 2019; pp. 1-21. [CrossRef]

22. Delplanque, M.; Collet, S.; Del Gratta, F.; Schnuriger, B.; Gaucher, R.; Robinson, B.; Bert, V. Combustion of Salix used for phytoextraction: The ate of metals and viability of the process. Biomass Bioenergy 2013, 49, 160-170. [CrossRef]

23. Bert, V.; Allemon, J.; Sajet, P.; Dieu, S.; Papin, A.; Collet, S.; Gaucher, R.; Chalot, M.; Michiels, B.; Raventos, C. Torrefaction and pyrolysis of metal-enriched poplars from phytotechnologies: Effect of temperature and biomass chlorine content on metal distribution in end-products and valorization options. Biomass Bioenergy 2017, 96, 1-11. [CrossRef]

24. Grignet, A.; De Vaufleury, A.; Papin, A.; Bert, V. Urban soil phytomanagment for Zn and Cd in situ removal, greening, and Zn-rich biomass production taking care of snail exposure. Environ. Sci. Pollut. Res. 2020, 27, 3187-3201. [CrossRef]

25. Ziegler-Devin, I.; Menana, Z.; Chrusciel, L.; Chalot, M.; Bert, V.; Brosse, N. Steam explosion pretreatment of willow grown on phytomanaged soils for bioethanol production. Ind. Crop Prod. 2019, 140. [CrossRef]

26. Asad, M.; Menana, Z.; Ziegler-Devin, I.; Bert, V.; Chalot, M.; Herzig, R.; Mench, M.; Brosse, N. Pretreatment of trace elementenriched biomasses grown on phytomanaged soils for bioethanol production. Ind. Crop Prod. 2017, 107, 63-72. [CrossRef]

27. Zheljazkov, V.D.; Craker, L.E.; Xing, B.; Nielsen, N.E.; Wilcox, A. Aromatic plant production on metal contaminated soils. Sci. Total Environ. 2008, 395, 51-62. [CrossRef] [PubMed]

28. Phanthavongsa, P.; Chalot, M.; Papin, A.; Lacercat-Didier, L.; Roy, S.; Blaudez, D.; Bert, V. Effect of mycorrhizal inoculation on metal accumulation by polar leaves at phytomanaged sites. Environ. Exp. Bot. 2017, 143, 72-81. [CrossRef]

29. Winchell, F.; Brass, M.; Manzo, A.; Belados, A.; Perna, P.; Murphy, C.; Stevens, C.; Fuller, D.Q. On the origins and dissemination of domesticated sorghum and pearl millet across Africa and into India: A View from the Butana group of the far Eastern Sahel. Afr. Archaeol. Rev. 2018, 35, 483-505. [CrossRef] [PubMed]

30. Steduto, P.; Katerji, N.; Puertos-Molina, H.; Ünlü, M.; Mastrorilli, M.; Rana, G. Water-use efficiency of sweet sorghum under water stress conditions gas-exchange investigations at leaf and canopy scales. Field Crop Res. 1997, 54, 221-234. [CrossRef]

31. Dahlberg, J.; Berenji, L.; Sikora, V.; Latkovic, D. Assessing sorghum [Sorghum bicolor (L) Moench] germplasm for new traits: Food, fuels \& unique uses. Maydica 2011, 56, 165-172.

32. Liu, Z.Q.; Li, H.L.; Zeng, X.J.; Lu, C.; Fu, J.Y.; Guo, L.J.; Kimani, W.M.; Yan, H.L.; He, Z.Y.; Hao, H.Q.; et al. Coupling phytoremediation of cadmium-contaminated soil with safe crop production based on a sorghum farming system. J. Clean. Prod. 2020, 275. [CrossRef]

33. Marchiol, L.; Fellet, G.; Perosa, D.; Zerbi, G. Removal of trace metals by Sorghum bicolor and Helianthus annuus in a site polluted by industrial wastes: A field experience. Plant Physiol. Biochem. 2007, 45, 379-387. [CrossRef]

34. Angelova, V.R.; Ivanova, R.V.; Delibaltova, V.A.; Ivanov, K.I. Use of sorghum crops for in situ Phytoremediation of polluted soils. J. Agric. Sci. Technol. 2011, 1, 691-702.

35. Xiao, M.Z.; Sun, R.; Du, Z.Y.; Yang, W.B.; Sun, Z.; Yuan, T.Q. A sustainable agricultural strategy integrating Cd-contmainated soils remediation and bioethanol production using sorghum cultivars. Ind. Crop Prod. 2021, 162, 113299. [CrossRef]

36. Li, Y.; Wang, Q.; He, L.Y.; Sheng, X.F. Increased growth and root Cu accumulation of Sorghum sudanense by endophytic Enterobacter sp. K3-2: Implications for Sorghum sudanense biomass production and phytostabilization. Ecotoxicol. Environ. Saf. 2016, 124, 163-168. [CrossRef]

37. Yuan, X.; Xiong, T.; Yao, S.; Liu, C.; Yin, Y.; Li, H.; Li, N. A real filed phytoremediation of multi-metals contaminated soils by selected hybrid sweet sorghum with high biomass and high accumulation ability. Chemosphere 2019, 237, 124536. [CrossRef]

38. Infoclimat.fr. Available online: https://www.infoclimat.fr/climatologie/annee/2019/lille-lesquin/valeurs/07015.html (accessed on 30 June 2020). 
39. Phanthavongsa, P. Etude de Deux Modalités de Phytomanagement Testées sur un Terrain de Gestion de Sédiments Contaminés par des Métaux et Métallö̈des. Ph.D. Thesis, Ecole Doctorale n ${ }^{\circ} 554$ Environnements-Santé, Université de Bourgogne FrancheComté, Besançon, France, April 2018.

40. Semencesdeprovence.com. Technical Cultural fiche of Sorghum Biomass. Available online: https:/ / www.semencesdeprovence. com/sorgho-ensilage-fourrager-biomasse/catalogue/biomass-133 (accessed on 24 June 2020).

41. Semencesdeprovence.com. Technical Cultural fiche of Sorghum Trudan Headless. Available online: https://www. semencesdeprovence.com/sorgho-ensilage-fourrager-biomasse/catalogue/trudan-headless (accessed on 24 June 2020).

42. ISO 19730:2008 (E.). Soil quality-Extraction of trace elements from soil using ammonium nitrate solution.

43. Komárek, M.; Chrastný, V.; Štíchová, J. Metal/metalloid contamination and isotopic composition of lead in edible mushrooms and forest soils originating from a smelting area. Environ. Int. 2007, 33, 677-684. [CrossRef] [PubMed]

44. Laboratoire Agronomique de Normandie. Available online: http://www.lano.asso.fr/web/matiere_organique.html. (accessed on 1 February 2021). (In Franch).

45. AIDA INERIS. Arrêté du 30/06/20 Modifiant L'arrêté du 9 Août 2006 Relatif aux Niveaux à Prendre en Compte Lors D'une Analyse de Rejets dans les Eaux de Surface ou de Sédiments Marins, Estuariens ou Extraits de Cours D'eau ou Canaux Relevant Respectivement des Rubriques 2.2.3.0, 3.2.1.0 et 4.1.3.0 de la Nomenclature Annexée à L'article R. 214-1 du Code de L'environnement. Available online: https:/ / aida.ineris.fr/consultation_document/43365 (accessed on 1 February 2021).

46. Toler, H.D.; Morton, J.B.; Cumming, J.R. Growth and metal accumulation of mycorrhizal sorghum exposed to elevated copper and zinc. Water Air Soil Pollut. 2005, 164, 155-172. [CrossRef]

47. Arvalis Info.fr Institut du Vegetal. Available online: https://www.arvalis-infos.fr/positionner-les-applications-selon-le-type-dadventices-@/view-15894-arvarticle.html (accessed on 9 October 2020).

48. Cabelguenne, M.; Marty, J.R.; Hilaire, A. Comparaison technico-économique de la valorisation de l'irrigation par quatre culture d'été (maïs, soja, sorgho, tournesol). Agron. EDP Sci. 1982, 2, 567-576. (In French) [CrossRef]

49. Hinsinger, P.; Plassard, C.; Tang, C.; Jaillard, B. Origins of root-mediated $\mathrm{pH}$ change in the rhizosphere and their responses to environmental constraints: A review. Plant Soil 2003, 248, 43-59. [CrossRef]

50. Kabata-Pendias, A. Trace Elements in Soils and Plants, 4th ed.; Taylor and Francis Group: Oxford, UK, 2011.

51. Soudek, P.; Rodriguez Valseca, I.M.; Petrová, Š.; Song, J.; Vaněk, T. Characteristics of different types of biochar and effects on the toxicity of heavy metal to germinating sorghum seeds. J. Geochem. Explor. 2017, 182, 157-165. [CrossRef]

52. Qiao, Y.; Crowley, D.; Wang, K.; Zhang, H.; Li, H. Effect of biochar and Arbuscular mycorrhizae on bioavailability of potentially toxic elements in an aged contaminated soil. Environ. Pollut. 2015, 206, 636-643. [CrossRef]

53. Hildebrandt, U.; Regvar, M.; Bothe, H. Arbuscular mycorrhiza and heavy metal tolerance. Phytochemistry 2007, 68, 139-146. [CrossRef] [PubMed]

54. Göhre, V.; Paszkowski, U. Contribution of the arbuscular mycorrhizal symbiosis to heavy metal phytoremediation Review. Planta 2006, 223, 1115-1122. [CrossRef]

55. Leung, H.M.; Wang, Z.W.; Ye, Z.H.; Yung, K.L.; Peng, X.L.; Cheung, K.C. Interactions between arbuscular mycorrhizae and plants in phytoremediation of metal-contaminated soils: A review. Pedosphere 2013, 23, 549-563. [CrossRef]

56. Epelde, L.; Mijangos, I.; Becerril, J.M.; Garbisu, C. Soil microbial community as bioindicator of the recovery of soil functioning derived from metal phytoextraction with sorghm. Soil Biol. Biochem. 2009, 41, 1788-1794. [CrossRef]

57. Barbanti, L.; Di Girolamo, G.; Grigatti, M.; Bertin, L.; Ciavatta, C. Anaerobic digestion of annual and multi-annual biomass crops. Ind. Crop Prod. 2014, 56, 137-144. [CrossRef]

58. Frigon, J.C.; Guiot, S.R. Biomethane production from starch and lignocellulosic crops: A comparative review. Biofuels Bioprod. Biorefining 2010, 4, 447-458. [CrossRef]

59. Bruni, E.; Jensen, A.P.; Pedersen, E.S.; Angelidaki, I. Anaerobic digestion of maize focusing on variety, harvest time and pretreatment. Appl. Energy 2010, 87, 2212-2217. [CrossRef]

60. Regulation (EU) 2019/1009 of the European Parliament and of the Council of 5 June 2019 laying down rules on the making available on the market of EU fertilising products and amending Regulations (EC) No 1069/2009 and (EC) No 1107/2009 and repealing Regulation (EC) No 2003/2003.

61. Alburquerque, J.A.; Gonzálvez, J.; Tortosa, G.; Baddi, G.A.; Cegarra, J. Evaluation of “alperujo" composting based on organic matter degradation, humifcation and compost quality. Biodegradation 2009, 20, 257-270. [CrossRef]

62. Clemens, S. How metal hyperaccumulating plants can advance Zn biofortification. Plant Soil 2017, 411, 111-120. [CrossRef]

63. Anderson, C.W.N.; Robinson, B.H.; West, D.M.; Clucas, L.; Portmann, D. Zinc-enriched and zinc-biofortified feed as a possible animal remedy in pastoral agriculture: Animal health and environmental benefits. J. Geochem. Explor. 2012, 121, 30-35. [CrossRef]

64. Vamerali, T.; Bandiera, M.; Lucchini, P.; Dickinson, N.M.; Mosca, G. Long-term phytomanagement of metal-contaminated land with field crops: Integrated remediation and biofortification. Eur. J. Agron. 2014, 53, 56-66. [CrossRef]

65. Wang, X.; Fernandes de Souza, M.; Li, H.; Tack, F.M.G.; Sik Ok, Y.; Meers, E. Zn phytoextraction and recycling of alfalfa biomass as potential Zn-biofortified feed crop. Sci. Total Environ. 2021, 760. [CrossRef] [PubMed]

66. Vintila, T.; Negrea, A.; Barbu, H.; Sumalan, R.; Kovacs, K. Metal distribution in the process of lignocellulosic ethanol production from heavy metal contaminated sorghum biomass. J. Chem. Technol. Biotechnol. 2016, 91, 1607-1614. [CrossRef] 
67. Almeida, L.G.F.d.; Parella, R.A.d.C.; Simeone, M.L.F.; Ribeiro, P.C.d.O.; Dos Santos, A.S.; Da Costa, A.S.V.; Guimaraes, A.G.; Schaffert, R.E. Composition and growth of sorghum biomass genotypes for ethanol production. Biomass Bionergy 2019, 122, 343-348. [CrossRef]

68. Directive 2002/32/EC of the European Parliament and of the Council of 7 May 2002 on undesirable substances in animal feed-Council statement. Official Journal L 140, 30/05/2002 P. 0010-0022. 